\title{
From Bottom to Top: Challenge on Formulating New Value Blueprint
}

\author{
Anita Maharani ${ }^{1}$, Harry Sutanto ${ }^{2}$, Synthia Atas Sari², Dianti Arudi ${ }^{2}$ \\ 1,2 Bina Nusantara University
}

\begin{tabular}{|c|c|}
\hline Article History & ABSTRACT \\
\hline \multirow[t]{2}{*}{$\begin{array}{l}\text { Received } 11.05 .2019 \\
\text { Received in revised form } \\
16.08 .2019 \\
\text { Accepted } 04.10 .2019 \\
\text { Available online } 28.10 .2019\end{array}$} & $\begin{array}{l}\text { This paper aims to disseminate an experiential report of a program conducted for } \\
\text { Mitsubishi Pet Film Indonesia (MFI) to change the organization. The company } \\
\text { asked us to develop both blueprint report and visual guidance report and } \\
\text { disseminate it through nine workshops conducted to Change Agent (CA). We as } \\
\text { consultant work together with the company to determine Change Agent, through } \\
\text { Focus Group Discussion within } 70 \text { employees chosen by the company, then } \\
\text { selected } 25 \text { out of } 70 \text { who then become the Change Agent. We implement John P. } \\
\text { Kotter, known as Kotter's } 8 \text { Step Change Model during the process, during the } \\
\text { process, both us and the company realize that although change process has been } \\
\text { made, it would not place any effect until a post majeure event. By one event, when } \\
\text { there was a fire in one of company's installation, Change Agents were actually } \\
\text { trained to implement change as it was hoped by the company. }\end{array}$ \\
\hline & KEYWORDS: Change, Company, Process, Program, Workshop. \\
\hline
\end{tabular}

DOI: $10.30653 / 002.201943 .148$

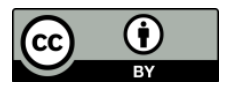

This is an open access article distributed under the terms of the Creative Commons Attribution 4.0 International License, which permits unrestricted use, distribution, and reproduction in any medium, provided the original work is properly cited. ○ 2019 Anita Maharani, Harry Sutanto, Synthia Atas Sari, Dianti Arudi.

\section{INTRODUCTION}

The urgency of change is really important these days. As any organization face turbulence in competition, traditional ways of doing business needs more than just a change, it also need a radical way of thinking from their support. Supports are from the system practice by the organization and also from both employers and employee, furthermore third party and stakeholders also have their rights to understand the necessity for change, and this would be considered as a supporting system. By the end of 2017, Mitsubishi Pet Film Indonesia (MFI) realize that they need to change their business. MFI invited us, as part of Binus Creates to help them on how to get the "change, and we also learn from them on how to understand that change is something that is unique, and it may be useful to understand how Kotter's idea of Change Steps really can be implemented.

${ }^{1}$ Corresponding author: Business Management Program, Management Department, BINUS Business School Master Program, Bina Nusantara University, Jakarta, Indonesia 11480; Email: anita.maharani@binus.edu 
On December 2017, we conduct a pitching session to MFI's Chief of Executive Officer, our Project Leader (PL) delivers title "Sharpening Corporate Culture Strategy to Form MC Pet Film Indonesia (MF) Transnational as a True Global KAITEKI Company. PL then stated three goals of this project, where the first goal is MFI will win the competition in dynamic global circumstances. The statement of winning the competition, will be best achieved through change, and as mentioned in early paragraphs, MFI will gain and deliver usefulness and benefits to all of it stakeholders, from being competitive. First, from the leadership or management role, in fact by the change will create awareness and engagement resulted from stakeholders as part of transformation process, and not to forget employees will gain more engagement through change process.

At the beginning, Project Leader describe the importance of the meeting, by acknowledging important principles, 1) Kaiteki, 2) MFI Vision, 3) Transnational company. The three principles was important. After the first meeting, we arrange another meeting with the management. By the second meeting, PL proposes MFI to develop the Guiding Team (GT) to help change process. As we believe that GT should promote specific characteristics, as follows: 1) they should have vision and perseverance, 2) they should able to build trust to the environment surrounds, 3) they need to counter intuitive or in other words should embrace uniqueness and strong will, 4) they should build and maintain the ability to accelerate employee eligibility. Second, we propose workshops series following Kotters Step to the management. We proposed this as we believe that the concept still relevant to be conducted nowadays. Workshops then will be followed first by 70 Change Agents (CA) candidate selected from 150 employees. The mechanism of selecting those 70 was done completely by the company using supervisor perception toward subordinates, following these characteristics: working experience (in years), working time, perceptions on four aspects (integrity, hard worker, communication skills, and open mindedness). Through this selection method, results in five Japanese employees, and 65 Indonesian employees, where the CA themselves were divided equally from management and non-management candidates.

From 70 employees that were nominated as $\mathrm{CA}$, then we as partner conduct another event to select representatives, we use a Focus Group Discussion in one day, parallel session between two big groups consists of 35 employees. In each group, there was two facilitators that will manage a whole day session and sharing their responsibility with one observer from Binus Creates. FGD was actually conducted within four sessions, to gain these objectives: 1) to evaluate CA candidates short term and long term orientation, 2) to evaluate the ability of CA to work within groups, 3) to evaluate CA knowledge of culture as this would work closely with change process and will be used for visual guidance overview that will be done separately after finish with 8 Steps workshops, 4) to evaluate CA candidates on their understanding toward themselves to stakeholders.

\section{METHODS}

Methods that has been conducted use multi approach, 1) survey, conducted two times, where first was to find CA candidates using several aspects conducted by internal management, the second to get an insight to CA candidates on their readiness for change perceptions and conducted by Binus Creates during FGD, 2) FGD, conducted after finish with first survey process to all of CA candidate, 3) Activity based workshops, was when 
CA selected and must follow a workshops series to develop their individual project of change, although in process they work in a team. We analyze these three methods through log diary, and minutes of meeting to see whether any possible unique event happening, and after the notes taking were done, we transfer it into two different reports, first is blueprint guidelines, second in visual guidelines.

\section{RESULT AND DISCUSSION}

Survey that first conducted through by the company resulted that CA was selected because supervisors believe in four aspects: integrity, hardworker, communication skills, and open mindedness, questions related with aspects, are as follows:

1) Integrity

"Imagine integrity of your candidate among your team members, how her/his level is?"

Responds range: low, average, high

2) Hardworker

"Imagine your candidate among your team member, does she/he a hardworker person?"

Responds range: under, average, above

3) Communication Skills

"Imagine communications skills of your candidate among your team members, how her/his level is?"

Responds range: low, average, good

4) Open mindedness

"Imagine how open mindedness your candidates among your team members?"

Responds range: low, average, yes

This method of survey was developed out of concepts known previously, and this probably would lead to respondent misinterpretation of understanding each aspect questioned. Where ideally, each aspect can be measured through a well-developed instrument, as follows: 1) integrity can be measured using Perceived Leader Integrity Scale (Craig, Gustafson, 1998), that believed may also be used when an organization would investigate role of leaders from the so called effectiveness of their ethical conduct and this survey may be done through subordinates. 2) Hardworker as adapted from hardwork as a condition where a person has two combinations at a time, that are time and intensity (Bowles, et al , 1984; Brown and Leigh, 1996; Douglas, 1989; Douglas and Shepherd, 2000, Douglas and Morris, 2006). 3) Communication Skills, as it has many dimensions and people methods on exchanging ideas and other things (Johnston, Fidelia, Robinson, Killion, Behrens, 2012) may be measured adapting Interpersonal Communication Skills Inventory or ICI (source: https://wicworks.fns.usda.gov, 2018) that is well known as selfassessment and will be suitable for every situations. 4) Open mindedness, as described as ability of someone to speak up their mind toward others and giving tolerance of others thought, can be measured using California Critical Thinking Disposition Inventory (CCTDI) (source: insightassessment.com, 2018). Therefore, since the organization conduct survey using their own scale of interpreting each aspect, we as partner should 
accommodate and develop a unique way to determine CA as it will be expected to do some actions within the organization.

Here are table, concerning activities done during Workshop 1 to Workshop 9, as it adapts Kotters' 8 Steps Model +1 . We state +1 to acknowledge that when it reaches the last workshop, it was actually beyond Kotters concept and it was an additional need to communicate change to parties. Within each activity, partners act as facilitator and participant will actively involve within the activities. Each workshop will be recorded using observations report from partner, and consolidations between partners and MFI's person in charge before conducting next workshops.

Table 1. Workshops Activity and Expected Outcome

\begin{tabular}{|c|c|c|}
\hline $\begin{array}{l}\text { Workshop } \\
\text { No. }\end{array}$ & Activities & Expected Outcome \\
\hline One & GT Role Development & $\begin{array}{l}\text { CA able to understand and implement what } \\
\text { is their position and why they selected as } \\
\text { CA, and what are things that expected from } \\
\text { them }\end{array}$ \\
\hline Two & $\begin{array}{l}\text { Understanding Behavior } \\
\text { and Key Performance } \\
\text { Indicator }\end{array}$ & $\begin{array}{l}\text { CA able to understand what are behaviors } \\
\text { that needed to become a CA, and how will it } \\
\text { affect or contribute to their KPI's }\end{array}$ \\
\hline Three & Plan for Change Behavior & $\begin{array}{l}\text { CA able to bring insight and ideas of ways of } \\
\text { changing people behavior }\end{array}$ \\
\hline Four & $\begin{array}{l}\text { Challenge and Evaluation } \\
\text { with Facilitator and Direct } \\
\text { Supervisors }\end{array}$ & $\begin{array}{l}\text { CA able to understand what current } \\
\text { situation within their organization is and } \\
\text { how will they actually have a role in }\end{array}$ \\
\hline Five & $\begin{array}{l}\text { Understanding Visual } \\
\text { Communication }\end{array}$ & $\begin{array}{l}\text { CA able to understand how to send message } \\
\text { using visual communication }\end{array}$ \\
\hline Six & Defining Key Behavior & $\begin{array}{l}\text { CA able to lists down what key behavior } \\
\text { should be embraced within employees and } \\
\text { promote by CA }\end{array}$ \\
\hline Seven & $\begin{array}{l}\text { Firm the Value and Learn } \\
\text { the Visual }\end{array}$ & $\begin{array}{l}\text { CA able to summarize, what may be the } \\
\text { value that they have decided on and how to } \\
\text { implement it through visuals aid }\end{array}$ \\
\hline Eight & $\begin{array}{l}\text { Action Plan Detail, Firm } \\
\text { the Tagline and Gain } \\
\text { Blueprint Data }\end{array}$ & $\begin{array}{l}\text { CA able to details action plan in order to } \\
\text { communicate change to their specific areas }\end{array}$ \\
\hline Nine & $\begin{array}{l}\text { Visual Communication } \\
\text { and Preparation of } \\
\text { Culture Day }\end{array}$ & $\begin{array}{l}\text { CA able to implement visual communication } \\
\text { to equip change plan and relates it with } \\
\text { culture day that will be conducted as their } \\
\text { inauguration day. }\end{array}$ \\
\hline
\end{tabular}

During partners involved in the activities, MFI itself has conducted KAITEKI, with some additional Indonesian culture and the management hopes that future vision also will exist. Some notes were taken during partners involved with the change process, are as follow. Although it was stated from the beginning that initiatives of change were decided by the management to be implemented within employees assigned as $\mathrm{CA}$, some 
obstacles appear during the process. First, there were resistances and doubt within CA about their role and how will it affect their expectancy on receiving benefits like incentives, career advancement. Second, whenever be situated within workshops, participants are more likely to be fixated on their anxiety and fear on peer pressures. Third, CEO was curious to see the change process within CA, however presence of CEO in the middle of workshops burden eagerness CA to involve and speak up. Fourth, when it comes to visual communications, both partners and management decided to meet before letting CA develop their own versions, technically this would not be easy since visual communications is not a daylight process.

However, although some obstacles were actually acceptable, there are things that need sto be highlighted during workshops activity. First, CA's were actually exploring their own words of "change" and translated into their own key behavior's. As partner, we use Kotter's Change Model to help the organization to understand ideal way to achieve change as intended to. And, the fact that before Workshop 7 were held, or by July $11^{\text {th }} 2018$ force majeure happened, where there was a fire in main plant, the urgency of change somehow was taken to surface, and promoted by the management, as they realize that the whole system was down temporary for six months ahead (and it still going on when this paper was written). Before this happened, MFI was known as a stable company, eventually after the fire solved, everyone was stunned and speechless, this as reported by one CA. But CA then realize their part, to mitigate trauma caused by fire together with the management, this can be considered as change program's maneuver. After all, key behaviors and any aspects resulted from Workshop one until six will be implemented without the wait to the whole employees of MFI.

\section{CONCLUSION}

This paper is aiming to describe the process of change adapting Kotter's 8 Steps Model. In fact, it was not as easy as written in the concept. Things that have not yet been notified in the concept was whether the model fits any organizations, especially when Top Management interfere process of change. However, this paper shows that CA can be managing to define their own change key behaviors, in other to formulate a new value blueprint.

\section{ACKNOWLEDGMENTS}

This paper acknowledges Binus Creates and MFI to support from the beginning until this paper was written. The advice and information in the conference are believed to be true and accurate on the date of its going to press, neither the authors, the editors, nor the publisher can accept any legal responsibility for any errors or omissions that may be made. The conference makes no warranty, express or implied, with respect to the material contained herein.

\section{REFERENCES}

Bowles, S., Gordon, D. M, \& Weisskopf, T. E. (1984). Beyond the wasteland: A democratic alternative to economic decline. London: Verso. 
Brown, S. P., \& Leigh, T. W. (1996). A new look at psychological climate and its relationship to job involvement, effort, and performance. Journal of Applied Psychology, 81(4), 358-368.

Craig, S. B., \& Gustafson, S. B. (1998). Perceived leader integrity scale: An instrument for assessing employee perceptions of leader integrity. The Leadership Quarterly, 9(2), 127-145. doi: 10.1016/S1048-9843(98) 90001-7

Douglas, E. J. (1989). The simple analytics of the principal-agent incentive contract. The Journal of Economic Education, 20(1), 39-51.

Douglas, E. J., \& Shepherd, D. A. (2000). Entrepreneurship as a utility maximizing response. Journal of Business Venturing, 15(3), 231-251.

Douglas, E. J., \& Morris, R. J. (2006). Workaholic, or just hard worker?. Career Development International, 11(5), 394-417.

Johnston, J., Fidelia, L., Robinson, K. W., Killion, J. B., \& Behrens, P. (2012). An instrument for assessing communication skills of healthcare and health services students. The Internet Journal of Allied Health Sciences and Practice, 10(4), 1-6. 